\title{
Antibacterial activity of neem nanoemulsion and its toxicity assessment on human lymphocytes in vitro
}

\author{
Jayakumar Jerobin \\ Pooja Makwana \\ RS Suresh Kumar \\ Rajiv Sundaramoorthy \\ Amitava Mukherjee \\ Natarajan Chandrasekaran
}

Centre for Nanobiotechnology, VIT University, Vellore, Tamil Nadu, India

Correspondence: Natarajan

Chandrasekaran

Centre for Nanobiotechnology,

VIT University, Vellore-6320I4,

Tamil Nadu, India

Tel +9| 4l 62202624

Fax +9| 4I 62243092

Email nchandrasekaran@vit.ac.in; nchandra40@hotmail.com
This article was published in the following Dove Press journal:

International Journal of Nanomedicine

I October 2015

Number of times this article has been viewed

\begin{abstract}
Neem (Azadirachta indica) is recognized as a medicinal plant well known for its antibacterial, antimalarial, antiviral, and antifungal properties. Neem nanoemulsion $(N E)(O / W)$ is formulated using neem oil, Tween 20 , and water by high-energy ultrasonication. The formulated neem NE showed antibacterial activity against the bacterial pathogen Vibrio vulnificus by disrupting the integrity of the bacterial cell membrane. Despite the use of neem NE in various biomedical applications, the toxicity studies on human cells are still lacking. The neem NE showed a decrease in cellular viability in human lymphocytes after 24 hours of exposure. The neem NE at lower concentration $(0.7-1 \mathrm{mg} / \mathrm{mL})$ is found to be nontoxic while it is toxic at higher concentrations $(1.2-2 \mathrm{mg} / \mathrm{mL})$. The oxidative stress induced by the neem NE is evidenced by the depletion of catalase, SOD, and GSH levels in human lymphocytes. Neem NE showed a significant increase in DNA damage when compared to control in human lymphocytes $(P<0.05)$. The NE is an effective antibacterial agent against the bacterial pathogen $V$. vulnificus, and it was found to be nontoxic at lower concentrations to human lymphocytes.
\end{abstract}

Keywords: neem, nanoemulsion, antibacterial, lymphocytes, cytotoxicity, genotoxicity

\section{Introduction}

The increase of antibacterial resistance is a major problem to be addressed in disease management. Vibrio vulnificus is an opportunistic human pathogen that is transmitted through seafood. The high virulence of the bacteria in humans is mainly due to two reasons. The first reason is the consumption of undercooked and raw sea foods by humans. The second reason is the exposure of human wound infections to sea water. ${ }^{1,2}$ People infected with $V$. vulnificus develop sepsis, severe cellulitis, fever, vomiting, and necrotizing fasciitis; one-third of the people develop septic shock. ${ }^{3}$ The development of alternative drugs and delivery systems has a vital role in the treatment of emerging bacterial infections. Nanotechnology-based applications in the medical field has gained popularity in recent years, especially in drug delivery, biomedical imaging, and therapeutics. ${ }^{4,5}$ Currently, different types of nanotechnology-based methods, including nanoemulsion (NE), nanoencapsulation, nanoliposomes, carbon nanotubes, and nanomicelles are used for delivering drugs to the target site without side effects. ${ }^{6,7}$ The use of NE systems in drug delivery applications has considerably increased in the last couple of years due to improved bioavailability, nontoxicity, physical stability, greater surface area, lower surface tension, and capability to be used as an effective substitute for liposomes. ${ }^{8}$

The NE has stable droplets in the size range of 1-100 nm prepared using oil and water and requires a low surfactant concentration. ${ }^{9}$ The NE can be formulated using submit your manuscript | www.dovepress.com

Dovepress

http://dx.doi.org/10.2147/IJN.S79983
International Journal of Nanomedicine 20I5:I0 (Suppl I: Challenges in biomaterials research) 77-86 77 (c) (i) (5) 2015 Jerobin et al. This work is published by Dove Medical Press Limited, and licensed under Creative Commons Attribution - Non Commercial (unported, v3.0) License. The full terms of the License are available at http://creativecommons.org/licenses/by-nc/3.0/. Non-commercial uses of the work are permitted without any further penw sion how to request permission may be found at: http://www.dovepress.com/permissions.php 
high-energy and low-energy methods. The low-energy method involves spontaneous emulsification, phase inversion point, and emulsion inversion point whereas the high-energy method involves ultrasonication, high-energy stirring, microfluidization, high-pressure homogenization, and membrane emulsification. Ultrasound-assisted emulsification is a facile, cost-efficient, and safer method for preparing NEs and has a commercial viability for the development of novel drugdelivery carriers. The recent literature in the field of NE suggests that acoustic-field generated cavitation bubbles tear-off the large oily emulsion droplets to nanoscale and has been successful in the preparation of herbal oil NEs. ${ }^{10-12}$ The use of ultrasonic cavitation forces for the preparation of neem NE has been reported in our previous study. ${ }^{13}$ Neem (Azadirachta indica) is a traditional plant that mainly grows in the Indian subcontinent and has been reported to have various clinical applications like antibacterial, ${ }^{14,15}$ antiviral, ${ }^{16}$ anticancer, ${ }^{17}$ and antidiabetic ${ }^{18}$ properties. The usage of herbal medicines to treat infections has been practiced since ancient days due to their eco-friendliness and low side effects. ${ }^{19}$ The neem oil offers antibacterial activity against pathogenic Vibrio sp., ${ }^{20}$ and the nanoformulation of neem oil will help enhance the antimicrobial property and stability. ${ }^{21}$ The in vivo toxicity assessments of the NE are necessary to determine the dosage and toxicity level before any therapeutic application to humans. ${ }^{22}$ The in vitro toxicity study on the immune cells is essential to assess the effects of the nanomaterial at the cellular level. ${ }^{23}$ The lymphocytes are immune cells that protect the humans against infections by humoral and cell-mediated immunity. ${ }^{24}$ The human lymphocytes are the most commonly used system to study the cytotoxicity and genotoxicity of the NEs prepared for therapeutic applications. ${ }^{25}$ The present study deals with the antibacterial activity of neem oil NE against $V$. vulnificus and the toxicity assessment of NE in cultured human lymphocytes.

\section{Materials and methods Chemicals and reagents}

Neem oil was purchased from Vellore, India. RPMI 1640 medium, fetal bovine serum (FBS), penicillin, streptomycin, low melting point agarose (LMPA), normal melting point agarose (NMPA), ethylenediaminetetraacetic acid (EDTA), ethidium bromide (EtBr), thiobarbituric acid (TBAR), tris buffer, 3-(4,5-dimethylthiazolyl-2)-2,5-diphenyltetrazolium bromide (MTT), Tween 20, and dimethyl sulfoxide (DMSO) were purchased from Sigma-Aldrich Co. (St Louis, MO, USA). Histopaque reagent and sterile discs were purchased from HiMedia laboratories, India. All other chemicals used were of the highest purity available from commercial sources.

\section{Neem NE}

The NE was formulated using the high-energy ultrasonication method (Vibra-Cell Ultrasonicator; $750 \mathrm{~W}, 20 \mathrm{kHz}$, Sonics Corp, USA). In the previous study done by our group, we have reported that NE was formulated using neem oil, Tween 20, and water. The nanodroplet size of the NE was measured using the dynamic light scattering technique (Particle size analyzer; Horiba, Japan). The formulated NE was used for antimicrobial activity and toxicity studies. ${ }^{13,26}$

\section{Antibacterial activity}

Bacterial culture

The bacterial culture of $V$. vulnificus was purchased from Microbial type cell culture (MTCC: 1145). The bacterial strain was confirmed using the biochemical reactions by Bergey's Manual of Systemic bacteriology and Finegold and Martin (1982). ${ }^{27}$

\section{Minimum inhibitory concentrations}

The minimum inhibitory concentrations (MIC) of NE was determined using the broth dilution method. The lowest concentration of the NE inhibiting the growth of the bacteria $\left(1 \times 10^{8} \mathrm{CFU} / \mathrm{mL}\right)$ was considered as the MIC. ${ }^{28}$

\section{Antibacterial activity by well diffusion and sterile disc method}

The sterile cotton swab containing the bacterial culture was swabbed in the Mueller-Hinton agar. Using a sterile well cutter, two wells of $8 \mathrm{~mm}$ diameter were punched in the agar. To one well NE was added, and to the other well saline was added as a control. At $37^{\circ} \mathrm{C}$, both the plates were incubated for 24 hours. The antibacterial activity of $V$. vulnificus was evaluated by measuring the zone of inhibition. The experiments were carried out in triplicates.

To the sterile disc, NE was added and dried at room temperature. A tetracycline disc was used as a positive control. The NE sterile disc and antibiotic tetracycline disc were carefully dropped to the surface of Mueller-Hinton agar containing the lawn of bacterial culture. The two discs were kept apart and pressed down firmly using sterile forceps. At $37^{\circ} \mathrm{C}$, the plates were incubated for 24 hours. The experiments were carried out in triplicates. ${ }^{29}$ 


\section{Membrane integrity}

The membrane integrity of the bacteria treated with NE was studied for $0-12$ hours. The bacterial cells at $1 \times 10^{8} \mathrm{CFU} / \mathrm{mL}$ treated with NE $\left(\mathrm{A}_{1}\right)$ were considered as the test sample and the bacterial cells not treated with NE were considered as a control. The bacterial cells that interacted with Triton X-100 $\left(\mathrm{A}_{0}\right)$ were considered as a positive control. The bacterial cells were centrifuged at $6,000 \times g$ for 10 minutes in order to release the cytoplasmic contents. The supernatant obtained was measured at $260 \mathrm{~nm}$ using UV spectrophotometer (Systronics 2201; India). The release of cytoplasmic contents was represented as percentage units of UV absorbing materials leaked out of the bacteria. It was calculated using the formula $\mathrm{A}_{1} / \mathrm{A}_{0} \times 100 .{ }^{30}$

\section{Scanning electron microscopy (SEM)}

The bacterial cells treated with and without NE were examined microscopically for any cellular damage. The cells were coated on a cover slip and dipped in $2.5 \%$ glutaraldehyde for 2 hours in order to fix the cells. After that, every 10 minutes the cells were dehydrated with water/alcohol solutions $(30 \%, 50 \%$, and $70 \%)$. The samples were then subjected to gold sputtering (Cressington 108 sputter coaters; UK) in an argon atmosphere and observed using high-resolution SEM (FEI Quanta FEG 200; USA).

\section{Toxicity studies}

\section{Isolation of human lymphocytes}

Blood was collected from healthy male volunteers, nonsmokers (age 21-25 years) $(n=6)$ according to the institutional guidelines (VIT University). The human lymphocyte cells were isolated from blood using lymphocyte separation media (HiSep ${ }^{\mathrm{TM}}$; HiMedia Laboratories, Mumbai, India). The lymphocyte layer present in the buffy coat were transferred to another sterile tube and washed with PBS twice. Finally, human lymphocytes were suspended in RPMI 1640 media supplemented with $1 \%$ penicillin, $1 \%$ streptomycin, and $10 \%$ FBS at $37^{\circ} \mathrm{C}$ for 24 hours with $5 \%$ carbon dioxide $\left(\mathrm{CO}_{2}\right) \cdot{ }^{31}$

\section{Cellular viability}

The human lymphocytes $\left(1 \times 10^{4}\right.$ cells $)$ were treated with NE at different concentrations $(0.7,1,1.2,1.5,1.7$, and $2 \mathrm{mg} / \mathrm{mL})$ in a $96-w e l l$ culture plate and incubated at $37^{\circ} \mathrm{C}$ for 24 hours with $5 \% \mathrm{CO}_{2}$. The cells were treated with $5 \mathrm{mg} / \mathrm{mL}$ solution of MTT $(20 \mu \mathrm{L} /$ well $)$ at $37^{\circ} \mathrm{C}$ for 4 hours in a $5 \% \mathrm{CO}_{2}$ incubator. Next, $50 \mu \mathrm{L}$ of DMSO was added, and the optical density was read using PowerWave X2 microplate reader (BioTek
Corp, USA) at $590 \mathrm{~nm}$ wavelength. The data are presented as mean $\pm \mathrm{SD} .{ }^{32}$

\section{Lactate dehydrogenase leakage (LDH)}

The LDH leakage assay is an alternative assay used to measure the cytotoxicity of NE on the basis of membrane integrity damage of human lymphocyte cells. The amount of enzyme released by the cell provides the extent of the cell membrane damage. The LDH activity was estimated by adding $0.1 \mathrm{~mL}$ of cell suspension, $0.1 \mathrm{~mL}$ of $30 \mathrm{mM}$ sodium pyruvate, $0.2 \mathrm{mM}$ TrisHCl, and $0.1 \mathrm{~mL}$ of $6.6 \mathrm{mM} \mathrm{NADH}$. The decrease in absorbance was measured at $340 \mathrm{~nm}$. The amount of LDH release was expressed in terms of percentage. ${ }^{33}$

\section{Oxidative stress}

Oxidative stress induced by NE in human lymphocytes was evaluated by reactive oxygen species (ROS) generation and the TBARS assay to study the level of lipid peroxidation (LPO) in cells. The cells were incubated with dichlorodihydro-fluorescein-diacetate (DCFH-DA) at $37^{\circ} \mathrm{C}$ for 30 minutes. The intensities of fluorescence were detected by $485 \mathrm{~nm}$ excitation wavelength and emission wavelength of $528 \mathrm{~nm}$. The values for ROS obtained were expressed as the fluorescence intensity percentage relative to the control wells. ${ }^{34}$ The LPO was measured by the TBARS assay that detects the formation of malondialdehyde (MDA). The absorbance was measured at $532 \mathrm{~nm}$ and expressed in nanomoles of MDA per mg protein. ${ }^{35}$

The catalase activity in human lymphocytes was estimated spectrophotometrically. ${ }^{36}$ Approximately $0.1 \mathrm{~mL}$ of cell suspension was added with $2 \mathrm{~mL}$ of $50 \mathrm{mM}$ phosphate buffer ( $\mathrm{pH} 7.0)$ and $1 \mathrm{~mL}$ of hydrogen peroxide $\left(\mathrm{H}_{2} \mathrm{O}_{2}\right)$ (30 $\mathrm{mM}$ phosphate buffer, $\mathrm{pH}$ 7). The decrease in the absorbance was measured spectrophotometrically at $240 \mathrm{~nm}$ for 3 minutes at 30-second intervals. Glutathione (GSH) level was estimated using Ellman's reagent. The absorbance was read at $412 \mathrm{~nm} .{ }^{37}$ Superoxide dismutase (SOD) is one of the most important antioxidant enzymes that catalyzes the dismutation of the superoxide anion into $\mathrm{H}_{2} \mathrm{O}_{2}$ and molecular oxygen. The SOD assay was performed using the kit obtained from Sigma-Aldrich (St Louis, MO, USA).

\section{Single cell gel electrophoresis assay (Comet assay)}

The comet assay was performed for examining the DNA damage in human lymphocytes. ${ }^{38}$ Twenty microliters of lymphocyte cell suspension was mixed with $110 \mu \mathrm{L}$ of $0.5 \%$ LMPA and applied to microscope slides precoated 
with $0.75 \%$ NMPA. A final layer of $0.5 \%$ LMPA was then added to the slides and immersed in ice-cold alkaline lysis solution (2.5 M NaCl, $10 \mathrm{mM}$ Tris, $100 \mathrm{mM}$ EDTA, 10\% DMSO, $1 \%$ Triton X-100, $\mathrm{pH} 10.0$ ) for at least 1 hour. The slides were incubated in ice-cold electrophoresis solution for 20 minutes, followed by electrophoresis at $15 \mathrm{~V}$ for $25 \mathrm{~min}-$ utes. Subsequently, the slides were neutralized (Tris $0.4 \mathrm{M}$, $\mathrm{pH} 7.5)$, and air dried. The slides were stained by spreading $0.1 \mathrm{~mL}$ EtBr $(20 \mu \mathrm{g} / \mathrm{mL})$. The analysis of comets was carried out using a fluorescence microscope (Leica DM-2500). The images were taken using the camera (Leica DFC-295) attached to the microscope. Comets were analyzed on the basis of tail DNA ( $\%$ tail DNA $=100-\%$ head DNA) for the quantification of DNA damage.

\section{Statistical analysis}

All the measurements were expressed as mean \pm SD. The statistical analysis of the data obtained was using one-way ANOVA followed by Dunnett's post hoc test using GraphPad Prism software v5. The differences were considered statistically significant if $P<0.05$.

\section{Results and discussion Neem NE}

The NE was formulated using suitable pharmaceutical ingredients by the ultrasonication approach. The NE $(\mathrm{O} / \mathrm{W})$ was prepared using neem oil, Tween 20, and water. The $1: 3$ ratio of the NE was found to be stable with a droplet size of $39.8 \mathrm{~nm}$ and polydispersity index of 0.209 (Figure 1). The obtained results were in agreement with that of our previous study, in which we have reported the formation of neem oil NE (1:3 ratio) droplets of size in the range of 30-70 nm and of spherical shape. ${ }^{13}$ Tween 20 was found to be a suitable surfactant for the formulation of NE since it is less affected by $\mathrm{pH}$, and is considered to be nontoxic and biocompatible. ${ }^{39}$ The stability of the NE can persist over many months to years due to the presence of the stabilizing surfactant that inhibits the coalescence of the nanodroplets. ${ }^{40,41}$

\section{Neem NE antibacterial activity}

The continuous usage of antibiotics to treat the pathogenic bacteria $V$. vulnificus has resulted in antimicrobial resistance; hence, the need for new antimicrobial agents is a matter of concern in recent times. ${ }^{42}$ The antibacterial activity of the NE was studied in the pathogenic bacteria $V$. vulnificus, and the lowest NE concentration that can inhibit the growth of the bacteria was determined by MIC. ${ }^{28}$ The MIC results had proven that the NE at the concentration of $150 \mu \mathrm{g} / \mathrm{mL}$ had antibacterial activity against the bacteria $V$. vulnificus. The antibacterial susceptibility test was determined by both well-diffusion and sterile-disc methods. ${ }^{29}$ The welldiffusion method showed that the NE at the concentration of $150 \mu \mathrm{g} / \mathrm{mL}$ exhibited a zone of inhibition of $15.3 \pm 0.5 \mathrm{~mm}$, and no zone of inhibition was observed in the control well. The NE-loaded sterile disc was compared with the commercially available antibiotic disc. The NE had a zone of inhibition of $21.6 \pm 1.5 \mathrm{~mm}$ whereas the commercially available tetracycline had a zone of inhibition of $32.3 \pm 1.5 \mathrm{~mm}$.

The antibacterial activity of the neem extracts showed $\mathrm{MIC}$ at $6 \mathrm{mg} / \mathrm{mL}$, but the $\mathrm{NE}$ at lower concentration

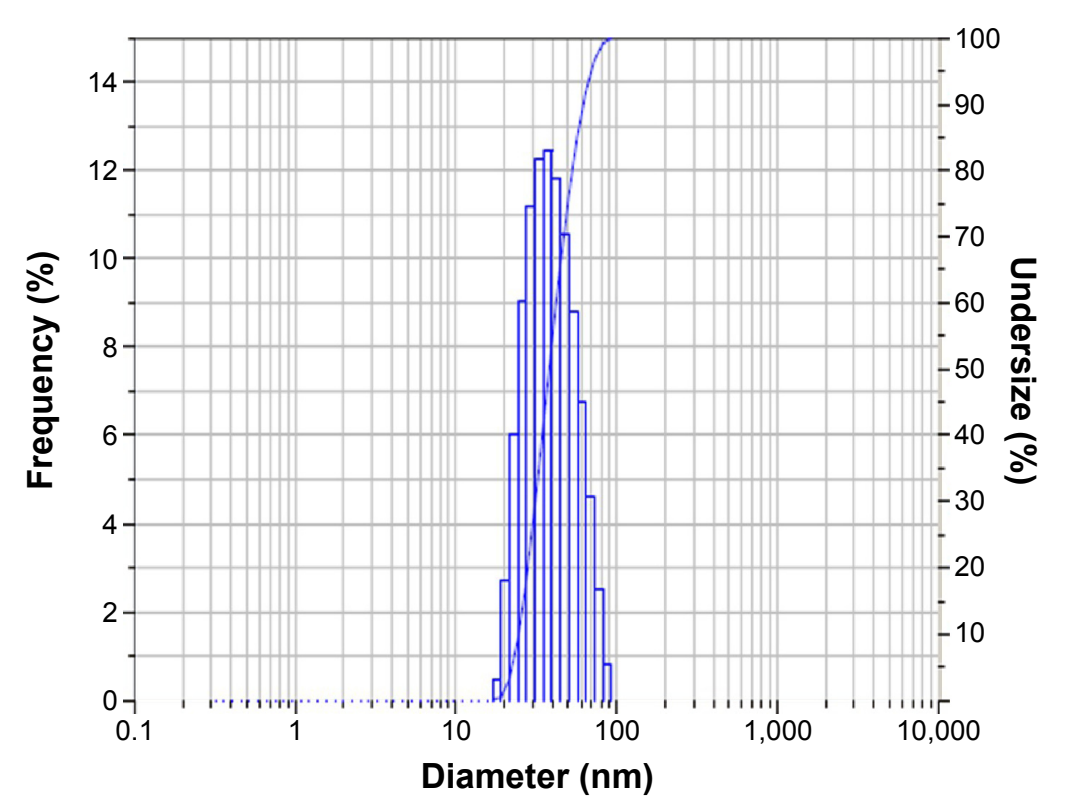

Figure I Droplet size distribution of the I:3 ratio of neem oil nanoemulsion. 
$150 \mu \mathrm{g} / \mathrm{mL}$ was found to be effective against the pathogenic bacteria $V$. vulnificus. ${ }^{43}$ The previous studies had proven that the NE was found to be an effective antibacterial agent against the bacteria Aeromonas salmonicida, Klebsiella pneumoniae, Vibrio sp., and Pseudomonas aeruginosa compared to neem oil. ${ }^{44-46}$ This was mainly due to the small droplet size of the NE, which was capable of more easily penetrating into the microbes than neem oil. The bacteria contain a high-lipid layer, and the high-lipid content was found to be less susceptible to antimicrobial agents. The NE prepared using the surfactant was capable of overcoming the lipid barriers and increase the susceptibility of the bacterial cells compared to the bulk material. ${ }^{47}$

\section{Membrane integrity and cell damage}

The antibacterial activity of NE was further confirmed by the membrane integrity and cell damage assessments of the bacteria. The membrane integrity of the NE was studied in V. vulnificus after exposing it to $150 \mu \mathrm{g} / \mathrm{mL} \mathrm{NE}$ at $0,3,6,9$, and 12 hours respectively. The NE-treated bacteria released $85.3 \%$ of the cytoplasmic contents when compared to control $12.6 \%$ (Figure 2). The membrane integrity of the bacteria was further studied by morphological changes examined by SEM; the damaged area in the bacterial cells is represented by white arrows (Figure 3A and B). The bacterial cells untreated with NE were found to be intact without any morphological changes. The NE-treated cells showed disruption and disintegration of the bacterial cell wall and a significant alteration in the morphological structure. Some parts of the membrane appear broken, and the leakage of intracellular constituents was clearly seen. These observations can be corroborated with the results of the membrane integrity assessment on bacteria.

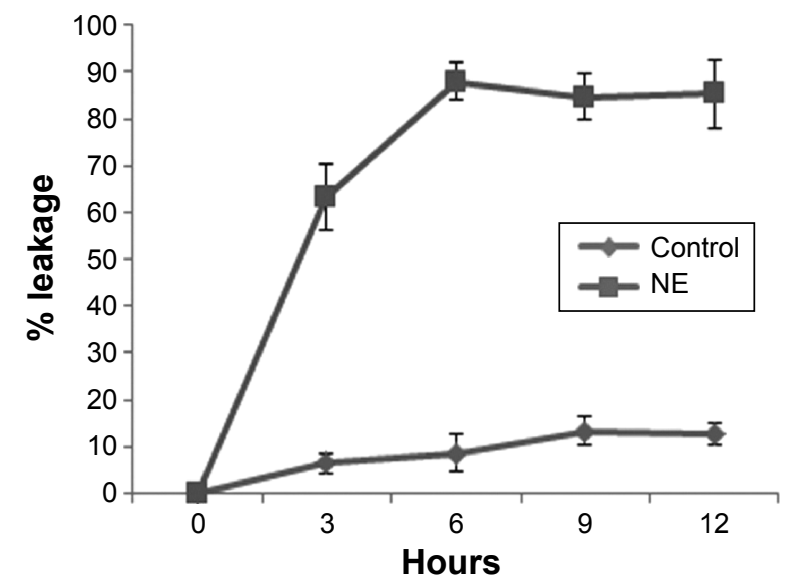

Figure 2 Leakage of cytoplasmic contents from Vibrio vulnificus treated with $150 \mu \mathrm{g} / \mathrm{mL}$ neem nanoemulsion.
The bacterial cell membrane is responsible for major functions such as osmoregulation, transport, lipid synthesis, and peptidoglycan cross-linking. The integrity of the bacterial membrane is necessary for survival, and its disruption can directly or indirectly lead to cell death. ${ }^{48,49}$ Similar to the toxicity of inorganic nanoparticles, NE toxicity to the bacterial cells depends on the NE surface composition and its interaction with the cell surface. ${ }^{50}$ The NE was able to disrupt the rod-shaped bacteria in a nonspecific way, leading to the alteration and leakage of cellular constituents. ${ }^{40}$ The solubility and bioavailability were a primary concern regarding the bulk material, and the micelle function of the NE was capable of damaging the bacterial surfaces by overcoming the insolubility barrier and penetrating into the bacterial cell. ${ }^{51,52}$ The NE plays a significant role in causing physical damage to bacteria, facilitating its use as an effective antibacterial agent as well as preventing them from developing resistance.

\section{Cytotoxicity of neem NE}

The human lymphocytes play a major role in the defense mechanism of infection, and the cultured human lymphocytes were used to study the in vitro toxicity assessment of the nanoparticles. ${ }^{53}$ The cytotoxicity of NE was evaluated in human lymphocytes by measuring the percentage of viable cells after 24 hours of interaction. The cytotoxicity of NE was evidenced by the decrease in cellular viability of lymphocytes in a time- and dose-dependent manner (Figure 4A). No significant decrease in cellular viability of lymphocytes was observed at NE concentrations of 0.7 and $1 \mathrm{mg} / \mathrm{mL}$ $(P>0.05)$. A significant decrease in cellular viability was observed at $1.2-2 \mathrm{mg} / \mathrm{mL}$, indicating the cytotoxicity of $\mathrm{NE}$ $(P<0.001)$. The cytotoxicity was further assessed by $\mathrm{LDH}$ leakage after 24 hours of interaction with NE. The human lymphocytes exposed to NE showed a significant increase in the LDH levels were observed for lymphocytes exposed to $\mathrm{NE}$ at $1.2 \mathrm{mg} / \mathrm{mL}(P<0.05)$ and $1.5-2 \mathrm{mg} / \mathrm{mL}(P<0.001)$ when compared to control. The NE showed a statistically insignificant increase in the LDH level at 0.7 and $1 \mathrm{mg} / \mathrm{mL}$ concentrations $(P>0.05)$ (Figure 4B).

The cytotoxicity study in human lymphocytes shows that $\mathrm{NE}$ at lower concentrations did not show any toxicity while at higher concentrations it was found to induce toxicity. Our results correlated with the study conducted on normal and tumor cells in which neem was found to be nontoxic to normal cells but toxic to the tumor cells. ${ }^{54}$ The previous toxicity report of neem extract components on human lymphocytes has showed that that neem's azadirachtin level greater than $1,000 \mu \mathrm{M}$ showed antiproliferative effects in the cultured human lymphocytes. ${ }^{55}$ In our previous study on the controlled 

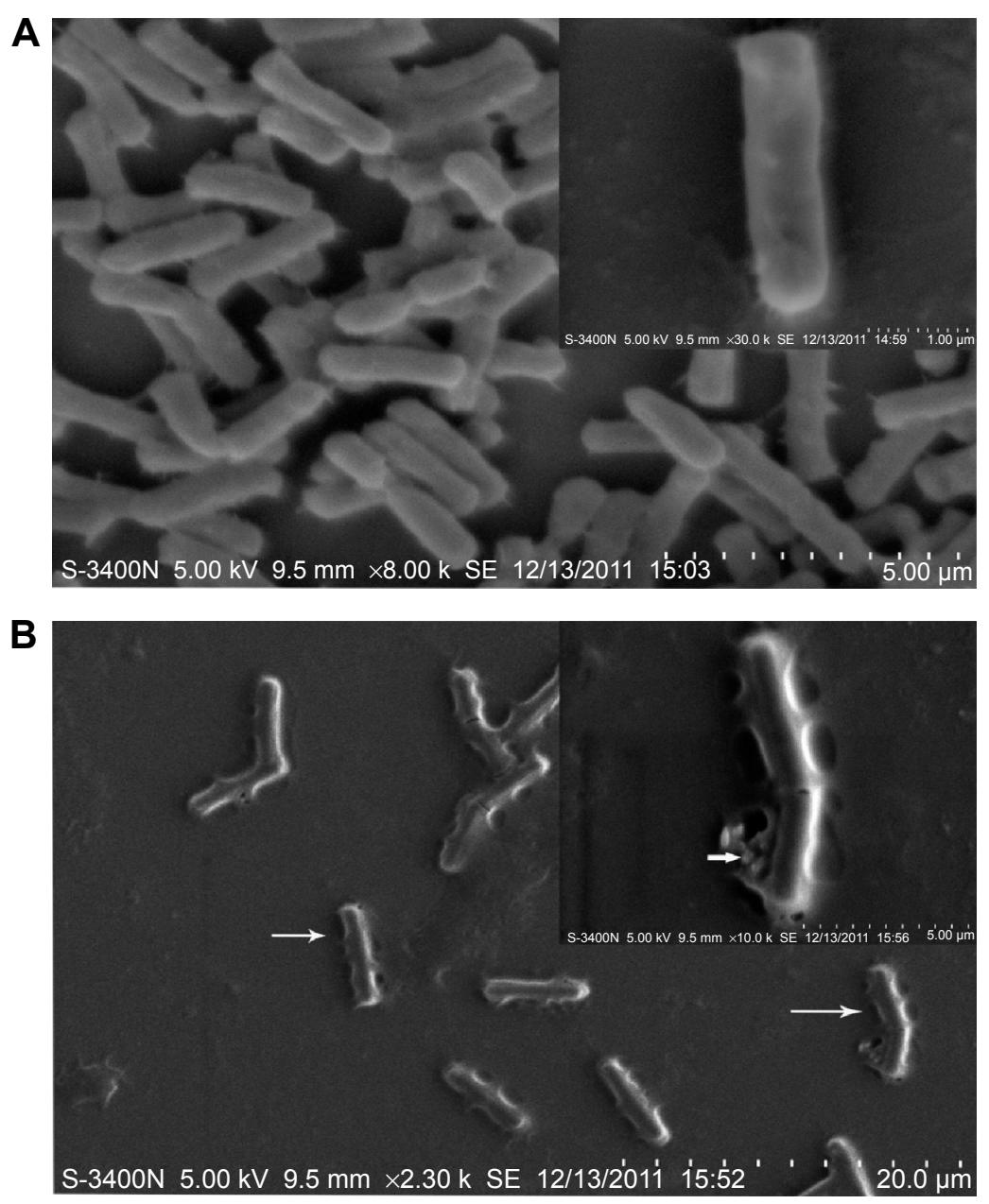

Figure 3 SEM images.

Notes: (A) control-untreated bacteria; (B) neem nanoemulsion-treated bacteria. The arrow (B) indicates damage to bacteria. The small arrow in the figure inset represent cell wall damage and leakage of intracellular contents.

Abbreviation: SEM, scanning electron microscopy.

release of neem NE, the NE encapsulated beads coated with $5 \%$ starch and PEG was found to be toxic when compared to the uncoated encapsulated NE beads in human lymphocytes. The cytotoxicity of $1 \%$ NE encapsulated beads was less toxic to human lymphocytes cells than $4 \%$ and $8 \%$ of neem oil encapsulated beads. ${ }^{26}$ The easy penetration of NE in to the human lymphocytes was the main reason for generation of the toxicity in a dose-dependent manner..$^{56}$ The contact of the NE to the human lymphocytes was able to damage the functions of mitochondria, and the cytotoxicity was mainly due to the induction of apoptosis through the mitochondrialdependent pathway. ${ }^{57}$
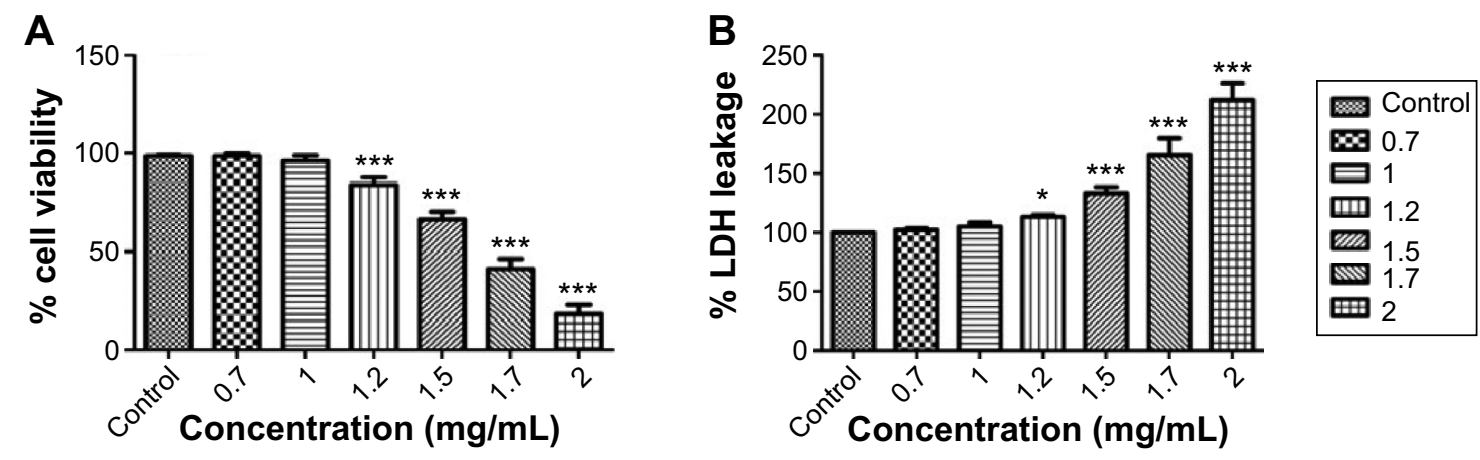

Figure 4 Cytotoxicity determined by cellular viability in human lymphocytes after 24 hours exposure to neem nanoemulsion.

Notes: (A) MTT; (B) LDH. Each value is represented in mean \pm SD. The significance versus control: $* P<0.05$, $* * P<0.0$ I, $* * * P<0.00$ I.

Abbreviations: MTT, 3-(4,5-dimethylthiazolyl-2)-2,5-diphenyltetrazolium bromide; LDH, lactate dehydrogenase. 


\section{Oxidative stress}

Oxidative stress was evidenced in human lymphocytes from the alteration in the level of ROS, LPO, and antioxidant enzymes. The ability of the NE to induce ROS in human lymphocytes cells was studied after 24 hours of incubation with the human lymphocyte cells. ${ }^{58}$ The cells after 24 hours of incubation showed a significant increase in the ROS level at $1.5 \mathrm{mg} / \mathrm{mL}(P<0.01), 1.7 \mathrm{mg} / \mathrm{mL}$ and $2 \mathrm{mg} / \mathrm{mL}(P<0.001)$. At $1.2 \mathrm{mg} / \mathrm{mL}$ of NE, no significant increase was observed $(P>0.05)$ (Figure 5A). The NE entering the cell cytoplasm induces the generation of ROS, which in turn causes oxidative stress condition in cells. ${ }^{59}$ This ROS production impairs the cellular function by damaging the intracellular components of a cell completely, including its proteins, lipids, and DNA. The LPO was assessed in human lymphocytes by estimating the level of MDA, a final product of lipid breakdown. ${ }^{52}$ The NE showed a significant increase in the LPO level after 24 hours of exposure $(P<0.001)$ (Figure 5B). The increase in the level of LPO was due to the degradation of polyunsaturated fatty acids causing damage to the membrane and structural integrity of human lymphocytes. ${ }^{60}$ The response of cells to oxidative stress was further studied by estimating the level of antioxidant enzymes catalase, SOD, and GSH. ${ }^{61}$ A significant decrease in the catalase level was observed at $1.2 \mathrm{mg} / \mathrm{mL}(P<0.05)$, $1.5-2 \mathrm{mg} / \mathrm{mL}(P<0.001)$. The NE showed a significant decrease in the GSH level at $1.2-2 \mathrm{mg} / \mathrm{mL}$, and a significant decrease in the SOD level was observed at $1.5 \mathrm{mg} / \mathrm{mL}$ $(P<0.05), 1.7-2 \mathrm{mg} / \mathrm{mL}(P<0.001)$ (Figure $6 \mathrm{~A}-\mathrm{C})$. The catalase, GSH, and SOD prevent the human lymphocytes from oxidative stress due to their capability to scavenge the ROS, and they are capable of creating a balance between the oxidant and the antioxidant process..$^{24,62}$ The oxidative stress generated in human lymphocytes was mainly due to the increase in the level of the ROS, and the depletion in the levels of the antioxidant enzymes catalase, GSH, and SOD when exposed to NE. ${ }^{58}$

\section{DNA damage}

The genotoxicity was mainly due to the DNA damage that occurs due to mutations, cross-linking, and adducts formation, leading to apoptosis in cells. The genotoxicity of the NE was studied in human lymphocytes using the comet assay. ${ }^{63,64}$ The $\%$ tail DNA in the treated cells increased from the lower $\mathrm{NE}$ concentration $1.2 \mathrm{mg} / \mathrm{mL}$ to the higher dose concentration $2 \mathrm{mg} / \mathrm{mL}$ indicating the genotoxicity of NE in human lymphocytes (Figure 7A-C). The NE-induced genotoxicity was less or negligible at lower concentrations, but it can lead to molecular and DNA level changes at higher concentrations. The NE-induced genotoxicity was mainly due to the uptake of droplets and the subsequent generation of oxidative stress, which in turn affects the chromosomes and the DNA. ${ }^{26,38,58}$ The NE was reported to cause DNA adducts, chromatid exchange, and DNA cross-linking in human lymphocytes. The induction of DNA damage can lead to the mutagenic and carcinogenic activity in human systems. ${ }^{65,66}$ In this study, $\mathrm{NE}$ at lower concentrations was not found to be genotoxic to human lymphocytes.

The ability of the NE to induce significant toxicity to bacteria at lower concentrations $(<1 \mathrm{mg} / \mathrm{mL})$ without any damage to lymphocytes may extend the possibilities for treatment of pathogenic bacteria in wound infections. The proposed strategy offers a significant opportunity to use neem NE along with pharmacologically active ingredients for various clinical applications. However, detailed investigations on the pharmacological properties of neem NE will help researchers to better understand its therapeutic role in the human systems.

\section{Conclusion}

NE was formulated using pharmaceutical ingredients, and it has potent antibacterial property. The NE at lower concentrations was nontoxic whereas at high concentrations of $1.2-2 \mathrm{mg} / \mathrm{mL}$
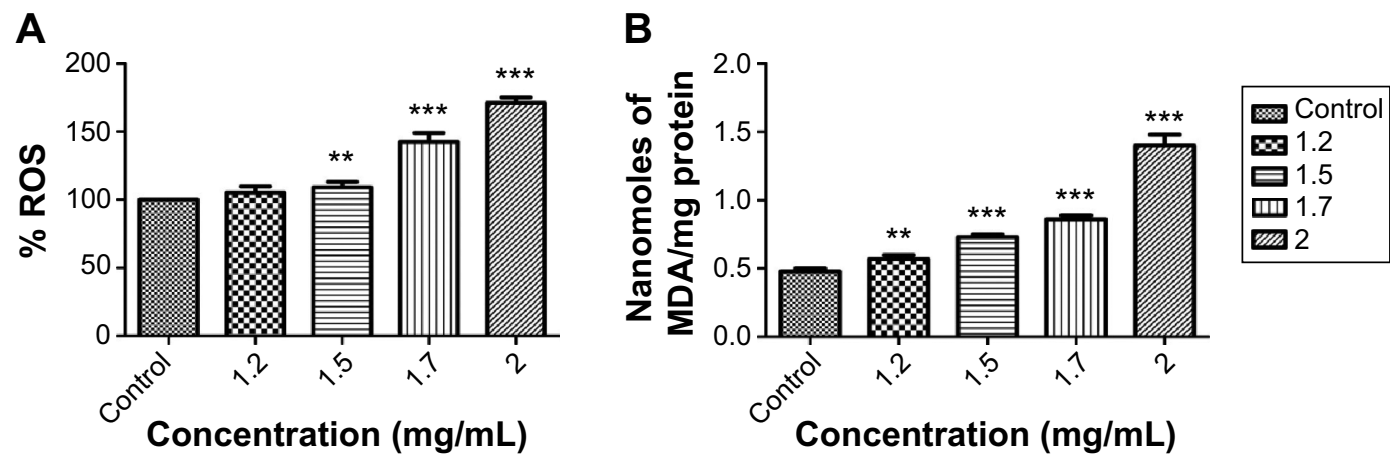

Figure 5 Oxidative stress generated in human lymphocytes after 24 hours exposure to neem nanoemulsion.

Notes: (A) ROS; (B) LPO. Each value is represented in mean \pm SD. The significance versus control: $* P<0.05, * * P<0.01, * * * P<0.001$.

Abbreviations: ROS, reactive oxygen species; LPO, lipid peroxidation; MDA, malondialdehyde. 


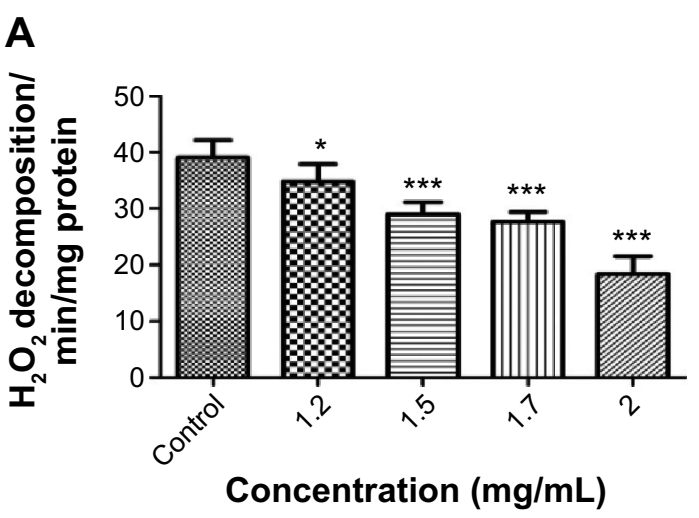

C

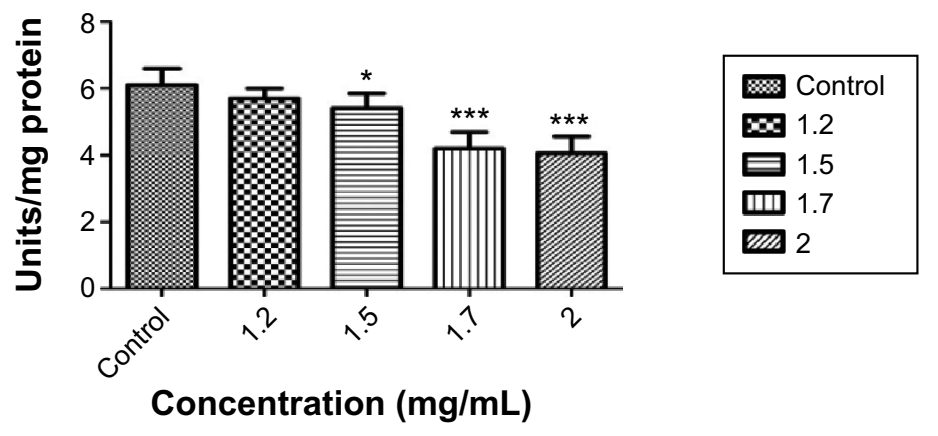

B

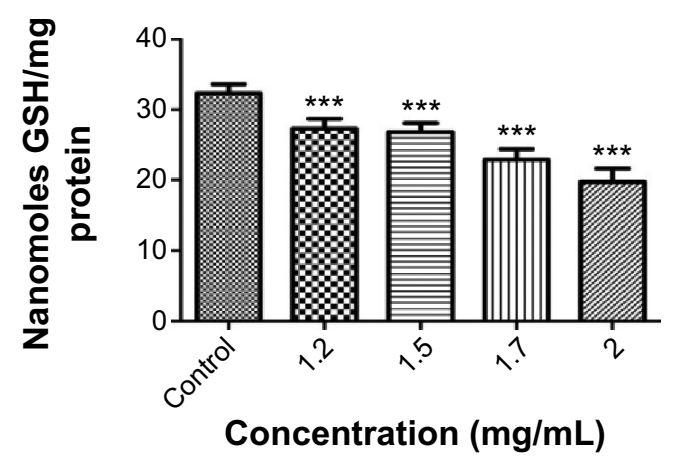

Figure 6 Antioxidant level after 24 hours of exposure to neem nanoemulsion.

Notes: (A) catalase; (B) GSH; (C) SOD. Each value is represented in mean \pm SD. The significance versus control: $* P<0.05, * * P<0.01, * * * P<0.00 \mathrm{I}$.

Abbreviations: $\mathrm{GSH}$, glutathione; $\mathrm{SOD}$, superoxide dismutase; $\mathrm{H}_{2} \mathrm{O}_{2}$, hydrogen peroxide.

\section{A}
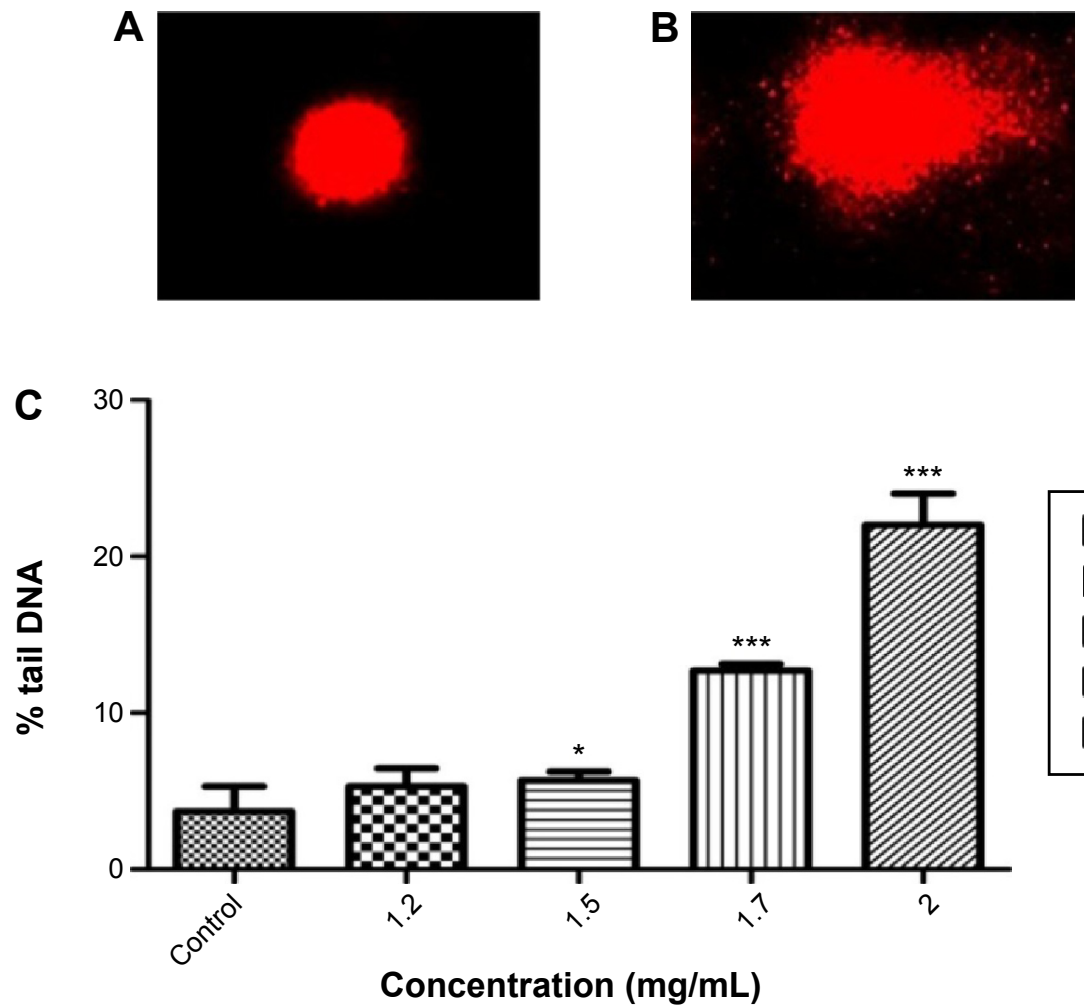

Figure 7 DNA damage in human lymphocytes assessed by comet assay.

Notes: $(\mathbf{A})$ control cells; $(\mathbf{B})$ lymphocytes exposed to neem nanoemulsion; $(\mathbf{C}) \%$ tail DNA. Each value is represented in mean $\pm \mathrm{SD}$. The significance versus control: $* P<0.05$, $* * \mathrm{P}<0.01$, *** $\mathrm{P}<0.001$. 
was found to be toxic to human lymphocytes. The cytotoxicity of NE leads to the formation of oxidative stress and DNA damage in human lymphocytes. This study has proven that the NE at lower concentrations can be used as an effective antibacterial agent for the treatment of pathogenic bacteria infections without any toxicity to the human system.

\section{Acknowledgment}

We would like to thank Johnson \& Johnson for sponsoring the paper and VIT University management for providing the lab facility.

\section{Disclosure}

The authors report no conflicts of interest in this work.

\section{References}

1. Kim JH, Choresca CH Jr, Shin SP, Han JE, Jun JW, Park SC. Occurence and antibiotic resistance of Vibrio vulnificus in seafood and environmental waters in Korea. J Food Saf. 2011;31(4):518-524.

2. Bross MH, Soch K, Morales R, Mitchell RB. Vibrio vulnificus infection: diagnosis and treatment. Am Fam Physician. 2007;74(4):539-544.

3. Han F, Walker RD, Janes ME, Prinyawiwatkul W, Ge B. Antimicrobial susceptibilities of Vibrio para haemolyticus and Vibrio vulnificus isolates from Louisiana Gulf and retail raw oysters. Appl Environ Microbiol. 2007;73(21):7096-7098.

4. Taylor E, Webster TJ. Reducing infections through nanotechnology and nanoparticles. Int J Nanomedicine. 2011;6:1463-1473.

5. Godin B, Sakamoto JH, Serda RE, Grattoni A, Bouamrani A, Ferrari M. Emerging applications of nanomedicine for therapy and diagnosis of cardiovascular diseases. Trends Pharmacol Sci. 2010;31(5):199-205.

6. Jong WHD, Borm PJ. Drug delivery and nanoparticles: applications and hazards. Int J Nanomedicine. 2008;3(2):133-149.

7. Safari J, Zarnegar Z. Advanced drug delivery systems: nanotechnology of health design a review. J Saudi Chem Soc. 2014;18(2):85-99.

8. Gutiérrez JM, González C, Maestro A, Solè I, Pey CM, Nolla J. Nanoemulsions: new applications and optimization of their preparation. Curr Opin Colloid Interface Sci. 2008;13(4):245-251.

9. Rezaee M, Basri M, Rahman RN, Salleh AB, Chaibakhsh N, Karjiban RA. Formulation development and optimization of palm kernel oil esters-based nanoemulsions containing sodium diclofenac. Int J Nanomedicine. 2014;9:539-548.

10. Sivakumar M, Tang SY, Tan KW. Cavitation technology - a greener processing technique for the generation of pharmaceutical nanoemulsions. Ultrason Sonochem. 2014;21(6):2069-2083.

11. Solè I, Maestro A, González C, Solans C, Gutiérre JM. Optimization of nano-emulsion preparation by low-energy methods in an ionic surfactant system. Langmuir. 2006;22(20):8326-8332.

12. Lovelyn C. Current state of nanoemulsions in drug delivery. J Biomater Nanobiotechnol. 2011;02:626-639.

13. Anjali CH, Sharma Y, Mukherjee A, Chandrasekaran N. Neem oil (Azadirachta indica) nanoemulsion a potent larvicidal agent against Culex quinquefasciatus. Pest Manag Sci. 2012;68(2):158-163.

14. Prabu seenivasan $S$, Jayakumar M, Ignacimuthu S. In vitro antibacterial activity of some plant essential oils. BMC Complement Altern Med.2006; 6(39): $1-8$.

15. Biswas K, Chattopadhyay I, Banerjee RK, Bandyopadhyay U. Biological activities and medicinal properties of neem (Azadirachtaindica). Curr Sci. 2002;82:1336-1345.

16. Tiwari V, Darmani NA, Yue BY, Shukla D. In vitro antiviral activity of neem (Azardirachta indica L.) bark extract against herpes simplex virus type-1 infection. Phytother Res. 2010;24(8):1132-1140.
17. Mahapatra S, Karnes RJ, Holmes MW, et al. Novel molecular targets of Azadirachta indica associated with inhibition of tumor growth in prostate cancer. AAPS J. 2011;13(3):365-377.

18. Gupta S, Kataria M, Gupta PK, Murganandan S, Yashroy RC. Protective role of extracts of neem seeds in diabetes caused by streptozotocin in rats. J Ethnopharmacol. 2004;90(2-3):185-189.

19. Srivastava JK, Shankar E, Gupta S. Chamomile: a herbal medicine of the past with bright future. Mol Med Rep. 2010;3(6):895-901.

20. Banerjee S, Kim LM, Shariff M, Khatoon H, Yusoff SM. Antibacterial activity of neem (Azadirachta indica) leaves on Vibrio spp. Isolated from cultured shrimp. Asian J Animal Veterinary Adv. 2012;3923:1-7.

21. Kurekci C, Padmanabha J, Bishop-Hurley SL, Hassan E, Al Jassim RA, McSweeney CS. Antimicrobial activity of essential oils and five terpenoid compounds against Campylobacter jejuni in pure and mixed culture experiments. Int J Food Microbiol. 2013;166(3):450-457.

22. Sood S, Jain K, Gowthamarajan K. Optimization of curcumin nanoemulsion for intranasal delivery using design of experiment and its toxicity assessment. Colloids Surf B Biointerfaces. 2014;113:330-337.

23. Anadon A, Martinez MA, Castellano V, Martínez-Larrañaga MR. The role of in vitro methods as alternatives to animals in toxicity testing. Expert Opin Drug Metab Toxicol. 2014;10(1):67-79.

24. Gautam N, Das S, Mahapatra SK, Chakraborty SP, Kundu PK, Roy S. Age associated oxidative damage in lymphocytes. Oxid Med Cell Longev. 2010;3(4):275-282.

25. Ghosh M, Chakraborty A, Mukherjee A. Cytotoxic, genotoxic and the hemolytic effect of titanium dioxide $\left(\mathrm{TiO}_{2}\right)$ nanoparticles on human erythrocyte and lymphocyte cells in vitro. J Appl Toxicol. 2013;33(10):1097-1110.

26. Jerobin J, Sureshkumar RS, Anjali CH, Mukherjee A, Chandrasekaran N. Biodegradable polymer based encapsulation of neem oil nanoemulsion for controlled release of Aza-A. Carbohydr Polym. 2012;90(4):1750-1756.

27. Finegold SM, Martin WJ. Diagnostic Microbiology, 6th edit., St Louis: C.V. Mosby Co. 1982

28. Witebsky FG, Maclowry JD, French SS. Broth dilution minimum inhibitory concentrations: rationale for use of selected antimicrobial concentrations. J Clin Microbiol. 1979;9(5):589-595.

29. Bauer AW, Kirby WM, Sherris JC, Turck M. Antibiotic susceptibility testing by a standardized single disk method. Am J Clin Pathol. 1966; 45(4):493-496.

30. Sugumar S, Nirmala J, Ghosh V, Anjali H, Mukherjee A, Chandrasekaran N. Bio-based nanoemulsion formulation, characterization and antibacterial activity against food-borne pathogens. J Basic Microbiol. 2013;53(8):677-685.

31. Ghiraldini F, Mello ML. Micronucleus formation, proliferative status, cell death and DNA damage in ethosuximide-treated human lymphocytes. Cell Biol Int Rep. 2010;17(1):27-31.

32. Suman G, Naravaneni R, Jamil K. In vitro cytogenetic studies of cypermethrin on human lymphocytes. Indian J Exp Biol. 2006;44: 233-239.

33. Pakrashi S, Dalai S, T CP, et al. Cytotoxicity of aluminium oxide nanoparticles towards fresh water algal isolate at low exposure concentrations. Aquat Toxicol. 2013;13(2-133):34-45.

34. Wang H, Joseph JA. Quantifying cellular oxidative stress by dichlorofluorescein assay using microplate reader. Free Radical Biol Med. 1999; 27(5-6):612-616.

35. Ohkawa H, Ohishi N, Yagi K. Assay for lipid peroxides in animal tissues by thiobarbituric acid reaction. Anal Biochem. 1979;95:351-358.

36. Sinha AK. Colorimetric assay of catalase. Anal Biochem. 1972;47: 389-394.

37. Ellman G. Tissue sulfhydryl groups. Arch Biochem Biophys. 1959;82: $70-77$.

38. Singh NP, McCoy MT, Tice RR, Schneider EL. A simple technique for quantitation of low levels of DNA damage in individual cells. Exp Cell Res. 1988;175(1):184-191.

39. Azeem A, Rizwan M, Ahmad FJ, et al. Nanoemulsion components screening and selection: a technical note. AAPS Pharm Sci Tech. 2009; 10(1):69-76. 
40. Sugumar S, Ghosh V, Nirmala MJ, Mukherjee A, Chandrasekaran N. Ultrasonic emulsification of eucalyptus oil nanoemulsion: antibacterial activity against Staphylococcus aureus and wound healing activity in Wistar rats. Ultrason Sonochem. 2014;21(3):1044-1049.

41. Tzoumaki MV, Moschakis T, Kiosseoglou V, Biliaderis CG. Oilin-water emulsions stabilized by chitin nanocrystal particles. Food Hydrocolloids. 2011;25(6):1521-1529.

42. Baker-Austin C, McArthur JV, Lindell AH, et al. Multi-site analysis reveals widespread antibiotic resistance in the marine pathogen Vibrio vulnificus. Microb Ecol. 2009;57(1):151-159.

43. Harikrishnan R, Kim M, Kim J, Balasundaram C, Jawahar S, Heo M. Identification and antimicrobial activity of combined extract from Azadirachta indica and Ocimum sanctum. Isr J Aquaculture. 2010;62(2): $85-95$.

44. Thomas J, Jerobin J, Seelan TS, et al. Study on pathogenecity of Aeromonas salmonicida in cat fish Clarias batrachus and control measures by neem nanoemulsion. Aquaculture. 2013;396(399):71-75.

45. Mishra P, Suresh Kumar RS, Jerobin J, Thomas J, Mukherjee A, Chandrasekaran N. Study on antimicrobial potential of neem oil nanoemulsion against Pseudomonas aeruginosa infection in Labeo rohita. Biotechnol Appl Biochem. 2014;61(5):611-619.

46. Jerobin J, Singh M, Sahni RD, Mukherjee A, Chandrasekaran N. Encapsulation of neem nanoemulsion for controlling urinary tract infection causing bacteria Klebsiella pneumoniae. J Neuroimmune Pharmacol. 2014;9(1):S30.

47. Gupta S, Bansal R, Ali J, Gabrani R, Dang S. Development and characterization of polyphenon 60 and caffeine microemulsion for enhanced antibacterial activity. Biomed Res Int. 2014;2014:932017.

48. Daima HK, Selvakannan PR, Kandjani AE, Shukla R, Bhargava SK, Bansal V. Synergistic influence of polyoxometalate surface corona towards enhancing the antibacterial performance of tyrosine-capped Ag nanoparticles. Nanoscale. 2014;6:758-765.

49. Connell S, Li J, Shi R. Synergistic bactericidal activity between hyperosmotic stress and membrane-disrupting nanoemulsions. J Med Microbiol. 2013;62:69-77.

50. Daima HK, Selvakannan PR, Shukla R, Bhargava SK, Bansal V. Finetuning the antimicrobial profile of biocompatible gold nanoparticles by sequential surface functionalization using polyoxometalates and lysine. PLoS One. 2013;8:e79676.

51. Hemmila MR, Mattar A, Taddonio MA, et al. Topical nanoemulsion therapy reduces bacterial wound infection and inflammation after burn injury. Surgery. 2010;148:499-509.

52. Jain N, Jain R, Thakur N, et al. Nanotechnology: a safe and effective drug delivery system. Asian J Pharm Clin Res. 2011;3(3):159-165.

53. Lankoff A, Arabski M, Wegierek-Ciuk A, et al. Effect of surface modification of silica nanoparticles on toxicity and cellular uptake by human peripheral blood lymphocytes in vitro. Nanotoxicology. 2013;7: $235-250$.
54. Ricci F, Berardi V, Risuleo G. Differential cytotoxicity of MEX: a component of neem oil whose action is exerted at the cell membrane level. Molecules. 2009;14(1):122-132.

55. Mosesso P, Bohm L, Pepe G, et al. Cytogenetic analyses of azadirachtin reveal absence of genotoxicity but marked antiproliferative effects in human lymphocytes and CHO cells in vitro. Toxicol Lett. 2012;213:361-366.

56. Mahmoudi M, Simchi A, Imani M, Milani AS, Stroeve P. An in vitro study of bare and poly (ethylene glycol)-co-fumarate-coated superparamagnetic iron oxide nanoparticles: a new toxicity identification procedure. Nanotechnology. 2009;20(22):225104.

57. Braun S, Gaza N, Werdehausen R, et al. Ketamine induces apoptosis via the mitochondrial pathway in human lymphocytes and neuronal cells. Br J Anaesth. 2010;105(3):347-354.

58. Alarifi S, Ali D, Alkahtani S, et al. Induction of oxidative stress, DNA damage, and apoptosis in a malignant human skin melanoma cell line after exposure to zinc oxide nanoparticles. Int J Nanomedicine. 2013;8: 983-993.

59. Akhtar MJ, Ahamed M, Kumar S, Khan MM, Ahmad J, Alrokayan SA. Zinc oxide nanoparticles selectively induce apoptosis in human cancer cells through reactive oxygen species. Int J Nanomedicine. 2012;7:845-857.

60. Yetuk G, Pandir D, Bas H. Protective role of catechin and quercetin in sodium benzoate-induced lipid peroxidation and the antioxidant system in human erythrocytes in vitro. Scientific World J. 2014;6:874824.

61. Hussain S, Slikker W, Ali F. Age-related changes in antioxidant enzymes, superoxide dismutase, catalase, glutathione peroxidase and glutathione in different regions of mouse brain. Int J Dev Neurosci. 1995; 13:811-817.

62. Cheng G, Guo W, Han L, et al. Cerium oxide nanoparticles induce cytotoxicity in human hepatoma SMMC-7721 cells via oxidative stress and the activation of MAPK signaling pathways. Toxicol in Vitro. 2011; 27(3):1082-1088

63. Greulich C, Diendorf J, Gessmann J. Cell type-specific responses of peripheral blood mononuclear cells to silver nanoparticles. Actabiomaterialia. 2011;7(9):3505-3514.

64. Alarifi S, Ali D, AO Y, Ahamed M, Siddiqui MA, Al-Khedhairy AA. Oxidative stress contributes to cobalt oxide nanoparticles-induced cytotoxicity and DNA damage in human hepato carcinoma cells. Int $J$ Nanomedicine. 2013;8:189-199.

65. Calderon-Segura ME, Gomez-Arroyo S, Villalobos-Pietrini R, et al. Evaluation of genotoxic and cytotoxic effects in human peripheral blood lymphocytes exposed in vitro to neonicotinoid insecticides news. J Toxicol. 2012;2012:612647.

66. Trouiller B, Reliene R, Westbrook A, Solaimani P, Schiestl RH. Titanium dioxide nanoparticles induce DNA damage and genetic instability in vivo in mice. Cancer Res. 2009;69:8784-8789.
International Journal of Nanomedicine

\section{Publish your work in this journal}

The International Journal of Nanomedicine is an international, peerreviewed journal focusing on the application of nanotechnology in diagnostics, therapeutics, and drug delivery systems throughout the biomedical field. This journal is indexed on PubMed Central, MedLine, CAS, SciSearch ${ }^{\circledR}$, Current Contents ${ }^{\circledR} /$ Clinical Medicine,

\section{Dovepress}

Journal Citation Reports/Science Edition, EMBase, Scopus and the Elsevier Bibliographic databases. The manuscript management system is completely online and includes a very quick and fair peer-review system, which is all easy to use. Visit http://www.dovepress.com/ testimonials.php to read real quotes from published authors. 